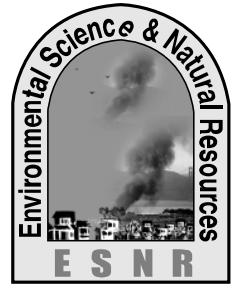

J. Environ. Sci. \& Natural Resources, 7(1): 75-79, 2014

ISSN 1999-7361

\title{
Effect of Inorganic Phosphorus Fertilizer and Inoculants on Yield and Phosphorus Use Efficiency of Wheat
}

\author{
M. B. Hossain and M. A. Sattar \\ Soil Science Division, Bangladesh Institute of Nuclear Agriculture (BINA) \\ Mymensingh 2200, Bangladesh
}

\begin{abstract}
To investigate the response of mineral phosphatic fertilizer and inoculum alone or integrated use of these sources on the growth, yield, nutrient uptake and phosphorus use efficiency of wheat. Treatment combinations were: $\mathrm{T}_{0}=$ Control, $\mathrm{T}_{1}=$ Pseudomonas sp, $\mathrm{T}_{2}=$ Klebsiella $\mathrm{sp}, \mathrm{T}_{3}=$ Pseudomonas $\mathrm{sp}+15 \mathrm{~kg} \mathrm{P} \mathrm{ha}^{-1}, \mathrm{~T}_{4}=$ Klebsiella $\mathrm{sp}+15 \mathrm{~kg} \mathrm{P} \mathrm{ha}^{-1}$ and $\mathrm{T}_{5}=30 \mathrm{~kg} \mathrm{P}^{-1}$. Trials were laid out in a randomized block design with four replications having unit plot size of $5 \mathrm{~m} \times 3 \mathrm{~m}$ and wheat was the test crop. Maximum grain and straw yield (2.13 and $2.84 \mathrm{t} \mathrm{ha}^{-1}$ ) were recorded in $\mathrm{T}_{3}\left(\mathrm{PSB} 7+15 \mathrm{~kg} \mathrm{P} \mathrm{ha}^{-1}\right)$ and $\mathrm{T}_{4}(\mathrm{PSB} 19+15 \mathrm{~kg} \mathrm{P}$ $\mathrm{ha}^{-1}$ ) treatments at Pabna and Rajshahi, respectively. Pseudomonas sp for Pabna and Klebsiella sp for Rajshahi along with triple super phosphate showed better performance than other treatments in respect of wheat yield, nutrient uptake and quality of soil. Phosphate solubilizing bacteria alone also increased phosphorus use efficiency during crop production. A positive significant correlation was observed between yield contributing characters and grain yield of wheat. Based on these reults it may be concluded that, phosphate solubilizing bacteria contributed from unavailable to available form of soil phosphorus and stimulated the available form of applied phosphatic fertilizer as a result increased nutrient uptake and yield of wheat
\end{abstract}

Key Words: Wheat, Phosphate solubilizing bacteria, Phosphorus use efficiency, Yield

\section{Introduction}

Wheat is the second most important cereal crop next to rice on the basis of cultivated area and production in Bangladesh (BBS, 2008). The farmers of Bangladesh usually do not follow improved management packages during crop production especially in problem soils. Poor socio-economic condition of the farmers and suitable technology are the main barrier behind it. Phosphorus is a nonrenewable source and a major plant nutrient for higher crop yield. It limits the crop production because only about $20 \%$ of applied phosphorus is utilized by crop and remaining part is converted into insoluble forms in acid and alkaline soils (Rodriguez and Fraga, 1990). In Bangladesh, most of the soils are acidic or alkaline nature (FRG, 2012) as a result, the availability of phosphorus for the nutrition of crops is very low due to its fixation excessive mineral phosphatic fertilizer creates eutrophication. Adequate supply of cost effective and environmental friendly phosphatic biofertilizer could play a vital role in improving the wheat yield as well as increases phosphorus use efficiency. In this context, Psolubilization ability of micro-organisms is considered to be one of the most important traits associated with plant $\mathrm{P}$ nutrition (Chen et al., 2006, Adesemoye and Kloepper, 2009). Several bacterial species are referred to as phosphate solubilizing bacteria (PSB) that have been considered as biofertilizer for improving the plant growth and yield of crops due to increase the availability of applied and soil phosphorus (Vessey, 2003). The beneficial effects of phosphate solubilizing bacteria on crop productivity have been widely described but the use of PSB as biofertilizer is scarcely documented in wheat. Be keeping in mind, the present investigations were planned to evaluate the performance of phosphate solubilizing bacteria either alone or in combination with triple super phosphate on wheat.

\section{Materials and Methods}

Field experiments were carried out at two locations of Bangladesh is situated between latitudes 20 34' and 26 38' north and latitudes 88 01' and 92 41' east. Two locations were Gangetic river flood plain at Pabna and Barind tract of Rajshahi in Bangladesh. Soil samples were randomly collected at $0-15 \mathrm{~cm}$ depth during the time of land preparation from several spots of the experimental land and composited it. The soils were sandy loam and clayey in texture having $\mathrm{pH} 7.5$ and 4.8 with 1.0 and 1.8 per cent organic matter, 0.11 and 0.13 per cent total nitrogen, 14.00 and 30.63 ppm P in Pabna and Rajshahi, respectively. The treatment combinations were : $\mathrm{T}_{0}=$ Control, $\mathrm{T}_{1}=$ Pseudomonas $\mathrm{sp}, \quad \mathrm{T}_{2}=$ Klebsiella $\mathrm{sp}, \mathrm{T}_{3}=$ Pseudomonas $\mathrm{sp}+15 \mathrm{~kg} \mathrm{P}^{-1}, \mathrm{~T}_{4}=$ Klebsiella $\mathrm{sp}+$ $15 \mathrm{~kg} \mathrm{P} \mathrm{ha}^{-1}$ and $\mathrm{T}_{5}=30 \mathrm{~kg} \mathrm{P} \mathrm{ha}^{-1}$. The trials were laid out in randomized block design using four replications having unit plot size of $5 \mathrm{~m} \times 3 \mathrm{~m}$ and wheat was the test crop. One third of $90 \mathrm{~kg} \mathrm{~N} \mathrm{ha}^{-1}$ as urea, $42 \mathrm{~kg} \mathrm{~K}_{2} \mathrm{O} \mathrm{ha}^{-1}$ as muriate of potash, $10 \mathrm{~kg} \mathrm{~S}^{-}$

${ }^{1}$ as gypsum and phosphorus as triple super phosphate as per treatment were applied at the time of final land 
preparation then mixed well with soil by spading. PSB application with seed coating at $7.5 \mathrm{~kg} \mathrm{ha}^{-1}$ of peat based carrier having a bacterial load of $10^{8}$ cells per gram. The rest $60 \mathrm{~kg} \mathrm{~N}$ as urea was applied in two splits at maximum vegetative phage and panicle initiation stage. Cultural practice was done whenever necessary. At harvesting stage, 10 plants were randomly selected and harvested from each unit plot to record yield contributing characters, grain and straw yield, nitrogen and phosphorus uptake in grain and straw. Dried seed and straw samples were digested in di-acid mixture of $\mathrm{HNO}_{3}: \mathrm{HClO}_{4}(9: 4)$ and phosphorus was determined by ascorbic acid reductant method (Watanabe and Olsen, 1965). Soil samples were analyzed to determine the content of phosphorus both at initial and after harvest of wheat. Recovery efficiency (RE) is uptake of phosphorus $(\mathrm{kg})$ by a wheat crop from $1 \mathrm{~kg}$ of applied phosphorus to the field. Recovery efficiency can be calculated by dividing agronomic use efficiency with physiological use efficiency.

$\mathrm{RE}=\frac{\left(\mathrm{U}-\mathrm{U}_{0}\right)}{\mathrm{P}}$

where $\mathrm{U}$ and $\mathrm{U}_{0}$ is $\mathrm{P}$ uptake in fertilized and unfertilized plot, respectively. $\mathrm{P}$ is triple super phosphate was applied in different treatments except control. Available phosphorus in post harvest soil was calculated using this formula

Available $\mathrm{P}=$ Amount of initial phosphorus in soil Amount of $\mathrm{P}$ in post harvest soil in different treatments

where amount of available phosphorus was expressed in $\mathrm{kg} \mathrm{ha}{ }^{-1}$. Data were statistically analyzed and Duncan's Multiple Range was applied to examine significant differences between the treatment means (Steel and Torrie, 1980).

Results
Pabna
The combined application of mineral phosphatic
fertilizer and inoculum contributed to increase yield
of wheat over control. Grain yield ranged from 1.53
to $2.13 \mathrm{t} \mathrm{ha}^{-1}$. The yield increase $(\%)$ was varied with
different treatments. Maximum yield $(39 \%)$ was
achieved in $\mathrm{T}_{3}\left(\right.$ Pseudomonas $\left.\mathrm{sp}+15 \mathrm{~kg} \mathrm{P} \mathrm{ha}^{-1}\right)$
followed by $\mathrm{T}_{4}(38 \%)$ and $\mathrm{T}_{5}(31 \%)$ treatments. The
minimum increase in grain yield $\left(1.53 \mathrm{t} \mathrm{ha}^{-1}\right)$ was
obtained from control plots. Higher grain yield in $\mathrm{T}_{3}$
treatment might have resulted from the favorable
effect of the number of effective tiller hill ${ }^{-1}$, filled
grain per panicle and 1000 seed weight. Straw yield
also showed a significant variation for different
treatments. Among the treatments, $\mathrm{T}_{5}\left(30 \mathrm{~kg} \mathrm{P} \mathrm{ha}^{-1}\right)$

produced the highest straw yield $\left(6.09 \mathrm{t} \mathrm{ha}^{-1}\right)$ and the lowest straw yield $\left(3.59 \mathrm{t} \mathrm{ha}^{-1}\right)$ was obtained from the control. Nitrogen uptake both in grain and straw was significantly influenced by different treatments. Maximum nitrogen uptake in grain $\left(36.72 \mathrm{~kg} \mathrm{ha}^{-1}\right)$ and straw $\left(18.23 \mathrm{~kg} \mathrm{ha}^{-1}\right)$ was found in $\mathrm{T}_{3}$ treatment and the minimum nitrogen uptake in grain $(26.94 \mathrm{~kg}$ $\mathrm{ha}^{-1}$ ) and straw (11.23 $\mathrm{kg} \mathrm{ha}^{-1}$ ) was obtained from $\mathrm{T}_{0}$ treatment. Combined application of mineral phosphatic fertilizer and inoculum $\left(\mathrm{T}_{3}\right)$ also increased the nitrogen uptake in grain of wheat which was identical to $\mathrm{T}_{4}, \mathrm{~T}_{1}, \mathrm{~T}_{5}$ and $\mathrm{T}_{2}$ treatments. Performance of Pseudomonas sp was better than that of Klebsiella $\mathrm{sp}$ in respect of nitrogen uptake in grain and straw of wheat. On the other hand, integrated application of mineral phosphatic fertilizer with inoculants significantly influenced the phosphorus uptake in grain and straw of wheat. Maximum phosphorus uptake in grain $\left(7.25 \mathrm{~kg} \mathrm{ha}^{-1}\right)$ and straw $\left(1.34 \mathrm{~kg} \mathrm{ha}^{-1}\right)$ was found in $\mathrm{T}_{3}$ treatment and the minimum phosphorus uptake in grain (3.94 kg ha $\mathrm{kg}^{-1}$ ) and straw $\left(0.47 \mathrm{~kg} \mathrm{ha}^{-1}\right)$ was obtained from $\mathrm{T}_{0}$ treatment. Pseudomonas $\mathrm{sp}$ in combination with $15 \mathrm{~kg} \mathrm{p} \mathrm{ha}^{-1}$ performed better results than that of $30 \mathrm{~kg} \mathrm{P} \mathrm{ha}^{-1}$ in respect of phosphorus uptake in grain and straw of wheat. From these results, it may be concluded that inoculum had good capacity to 50 per cent mineral phosphorus in wheat production. Grain yield was significantly correlated with yield contributing characters (plant height, spike length, tiller number, filled grain, unfilled grain and 1000 seed weight) of wheat (Table 2). Recovery efficiency of phosphorus ranged from 0.09 to 1.16 per cent. Maximum phosphorus use was observed in $\mathrm{T}_{1}$ treatment and the minimum phosphorus use efficiency was found in 30 $\mathrm{kg} \mathrm{P} \mathrm{ha}{ }^{-1}$ treatment. Available phosphorus in post harvest soil varied from -0.22 to $15.8 \mathrm{~kg} \mathrm{P}^{-1}$ with lowest (negative trend) in control and the highest in Pseudomonas sp in combination with $15 \mathrm{~kg} \mathrm{P} \mathrm{ha}^{-1}$.

\section{Rajshahi}

Results on the effect of mineral phosphatic fertilizer and inoculum are presented (Table 1). Grain yield ranged from 1.81 to $2.84 \mathrm{t} \mathrm{ha}^{-1}$. The yield increase (\%) was varied with different treatments. Maximum yield $(57 \%)$ was achieved in $\mathrm{T}_{4}$ (Klebsiella $\mathrm{sp}+15 \mathrm{~kg}$ $\mathrm{P} \mathrm{ha}^{-1}$ ) followed $\mathrm{T}_{3}(54 \%)$ and $\mathrm{T}_{5}(34 \%)$ treatments. The minimum grain yield $\left(1.81 \mathrm{t} \mathrm{ha}^{-1}\right)$ was obtained from control plots. Straw yield was showed a significant variation for different treatments. Among the treatments, $\mathrm{T}_{4}$ (Klebsiella $\mathrm{sp}+15 \mathrm{~kg} \mathrm{P} \mathrm{ha}^{-1}$ ) produced the highest straw yield $\left(6.69 \mathrm{t} \mathrm{ha}^{-1}\right)$ and the lowest straw yield (4.14 tha has found in control. Nitrogen uptake both grain and straw was significantly influenced by different treatments. Maximum nitrogen uptake in grain (42.74 $\mathrm{kg} \mathrm{ha}^{-1}$ ) 
and straw $\left(22.05 \mathrm{~kg} \mathrm{ha}^{-1}\right)$ was found in $\mathrm{T}_{4}$ and the minimum nitrogen uptake in grain $\left(28.53 \mathrm{~kg} \mathrm{ha}^{-1}\right)$ and straw $\left(13.34 \mathrm{~kg} \mathrm{ha}^{-1}\right)$ was obtained from $\mathrm{T}_{0}$ treatment. Combined application of mineral phosphatic fertilizer and inoculum $\left(\mathrm{T}_{4}\right)$ increased the nitrogen uptake in wheat grain markedly which was identical in $\mathrm{T}_{3}, \mathrm{~T}_{5}$, $\mathrm{T}_{2}$ and $\mathrm{T}_{1}$ treatments. Performance of Klebsiella $\mathrm{sp}$ was better than that of Pseudomonas sp in respect of nitrogen uptake in grain and straw of wheat. Similar trend was found in phosphorus uptake in grain and straw of wheat. Performance of Klebsiella sp in combination with $15 \mathrm{~kg} \mathrm{p} \mathrm{ha}^{-1}$ was better than that of $30 \mathrm{~kg} \mathrm{P} \mathrm{ha}^{-1}$ in respect of phosphorus uptake in wheat
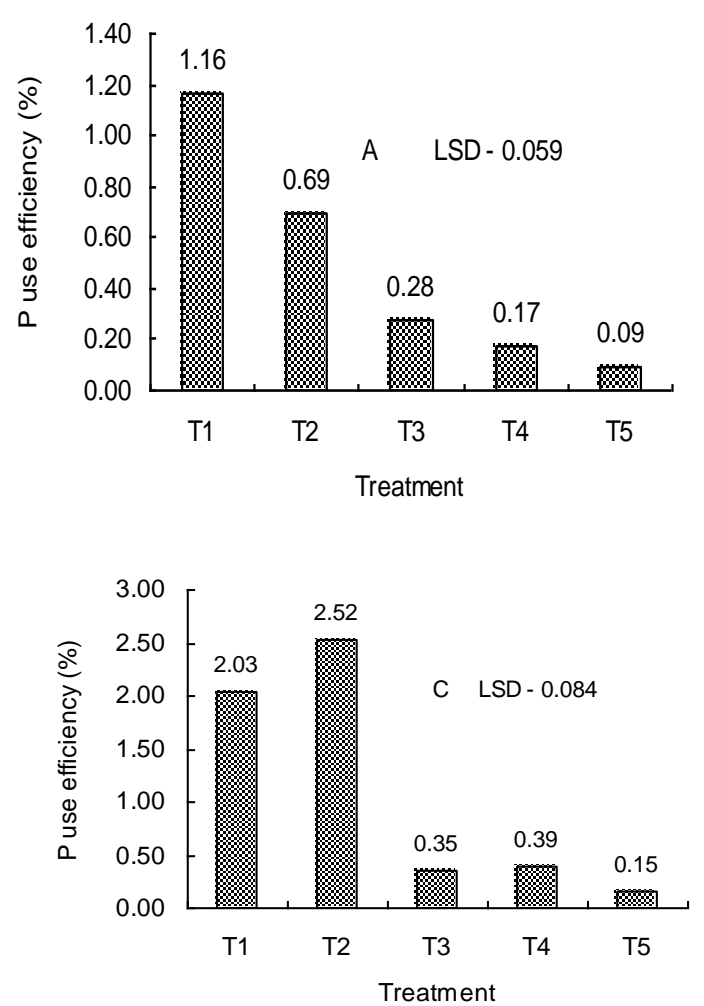

grain. The results in table 2 revealed that grain yield was significantly correlated with yield contributing characters (plant height, spike length, tiller number, filled grain, unfilled grain and 1000 seed weight) of wheat. Recovery efficiency of phosphorus ranged from 0.15 to 2.52 per cent. The maximum phosphorus use efficiency was observed in $\mathrm{T}_{2}$ treatment and the minimum phosphorus use efficiency was found in 30 $\mathrm{kg} \mathrm{P} \mathrm{ha}{ }^{-1}$ treatment. Available phosphorus in post harvest soil varied from -6.3 to $0.8 \mathrm{~kg} \mathrm{P} \mathrm{ha}^{-1}$ with lowest (negative trend) in control and highest in the Klebsiella sp in combination with $15 \mathrm{~kg} \mathrm{P} \mathrm{ha}^{-1}$.
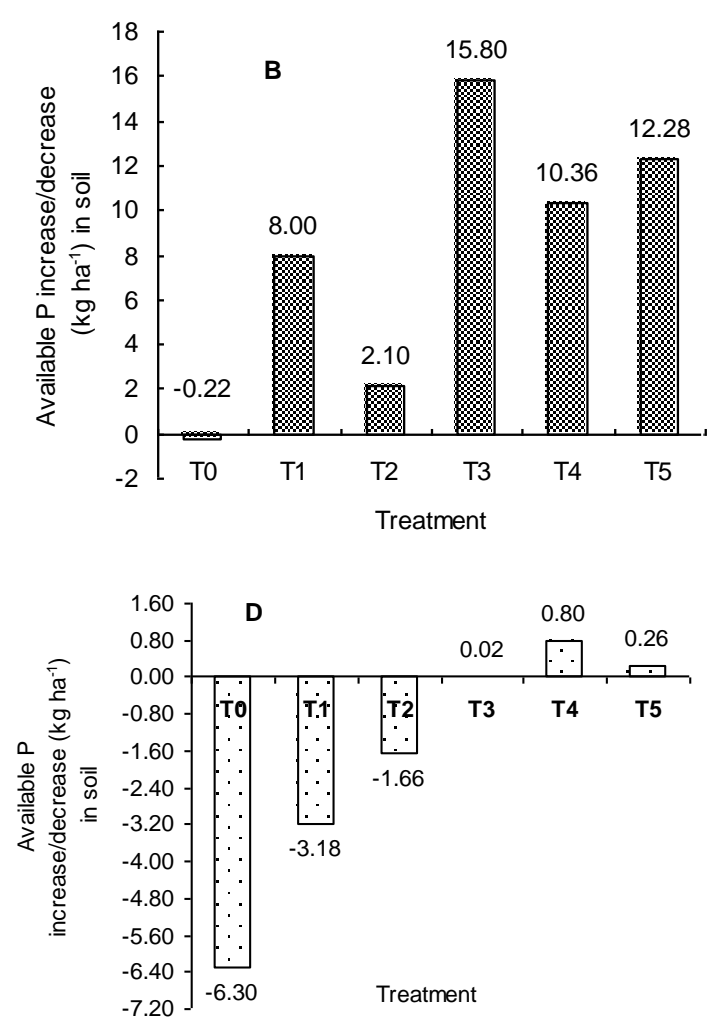

Fig. 1. Effect of chemical phosphorus fertilizer and inoculants on phosphorus use efficiency of wheat (A \& BPhosphorus use efficiency and available phosphorus in soil at Pabna, C \& D- Phosphorus use efficiency and available phosphorus in soil at Rajshahi

\section{Discussion}

Triple super phosphate (TSP) in combination with phosphate solubilizing bacteria had a significant effect on yield of wheat. Soil microorganisms are enormous potential in providing soil phosphates for plant growth. Phosphatic biofertilizer in the form of microorganisms can help in increasing the availability of fixed phosphates for plant growth by solubilization (Ekin, 2010, Shah et al., 2001 and Richardson, 2001). Pseudomonas sp had a stimulatory effect on wheat, maize and cotton growth, yield, N, P uptake and soil
P content (Egamberdiyeva et al., 2004). From this studied observations Pseudomonas sp and Klebsiella $\mathrm{sp}$ alone or in combination with triple super phosphate showed different yield performance of wheat at different locations because microrganisms behaved differently at different environmental conditions due to their adaptation capacity into the soil after inoculation. The correlation coefficients of all the above mentioned parameters (Table 2) helped to improve yield of wheat. Because yield of wheat increased with the increase of spike length, tiller per 
hill, filled grain per plant and decreasing unfilled grain per plant. Positive influence of treatments on available phosphorus content in soil was markedly changed in these results. Phosphate solubilizing bacteria contributed from unavailable to available form of soil phosphorus and stimulated the available form of applied phosphatic fertilizer as a result increased the phosphorus content in postharvest soil (Kumar and Narula, 2001). Soil phosphate is rendered available either by plant roots or by soil microorganisms through secretion of organic acids (formic, acetic, propionic, lactic glycolic, fumaric and succinic acids). These organic acids play in correcting phosphorus deficiency for crop plants (Cakmakci et al., 2006). Last of all, our results showed that the possibility of partial substitution of phosphorus using phosphate solubilizing bacteria, without any reduction of yield in wheat. Pseudomonas sp and Klebsiella sp in combination with $15 \mathrm{~kg} \mathrm{P} \mathrm{ha}{ }^{-1}$ was enough to ensure the standard level of yield. Therefore, these results indicated that the best management of phosphatic fertilizer with phosphate solubilizing bacteria ensured good yield as well as to enrich phosphorus in soil.

\section{References}

Bangladesh Bureau of Statistic's (BBS). 2008. Statistical Yearbook of Bangladesh. $21^{\text {st }}$ Edn. Bangladesh Bureau of Statistics. Ministry of Planning. Government of the People's Republic of Bangladesh, Dhaka.

Rodriguez, D. and Fraga, R. 1999. Phosphate solubilizing bacteria and their role in plant growth promotion. Biotechnol. Adv. 17: 319339.

Chen, Y. P.; Rekha, P.D.; Arun, A.B.; Shen, F.T.; Lal, W.A. and Young, C.C. 2006. Phosphate solubilizing bacteria from subtropical soil and their tricalcium phosphate solubilizing abilities. Appl. Soil Ecol. 34: 33-41.

Adesemoye, A.O. and Kloepper, J.W. 2009. Plant microbes interaction in enhanced fertilizer use efficiency. Appl. Microbiol. Biotechnol. 85: 112.

Vessey, K.J. 2003. Plant growth promoting rhizobacteria as biofertilizers. Plant Soil, 255: 123-129.
Watanabe, F.S. and Olsen, S.R. 1965. Test of ascorbic acid method for determining phosphorus in water and sodium bicarbonate extracts of soil. Proc. Soil Sci. Soc. Am. 29: 677-678.

Steel, R.G.D. and Torrie, J.H. 1980. Principles and Procedure of Statistics. Mc Graw Hill Book Co. Inc. New York, USA.

Ekin, Z. 2010. Performance of phosphate solubilizing bacteria for improving and yield of sunflower (Helianthus annuus L) in the presence of phosphorus fertilizer. African J. of Biotechnology. 9(25): 3794-3800.

Shah, P.; Kakar, K.M. and Zada, K. 2001. Phosphorus use efficiency of soybean as affected by phosphorus application and inoculation. In: Horst, W.J., (Eds.), Plant Nutrition-Food Security and Sustainability of Agroecosystems. pp. 670-671.

Richardson, A.E. 2001. Prospects for using soil microorganisms to improve the acquisition of phosphorus by plants. Aust. J. Plant Physiol. 28: 8797-8806.

Egamberdiyeva, D.; Juraeva, D.; Poberejskaya, S.; Myachina, O.; Teryuhova, P.; Seydalieva, L. and Aliev, A. 2004. Improvement of wheat and cotton growth and nutrient uptake by phosphate solubilizing bacteria. Proc. of the $26^{\text {th }}$ Sourthern Conservation Tillage Conf. for Sustainable Agriculture. Raleigh, North Carolina. pp. 58-66.

Kumar, V. and Narula, N. 2001. Establishment of phosphate solubilising strains of Azotobacter chroococuum in the rhizosphere and their effect on wheat cultivars under greenhouse conditions. Microbiol. Res. 156: 87-93.

Cakmakci, R.; Donmez, F.; Aydin, A. and Sahin, F. 2006. Growth promotion of plants by plant growth promoting rhizobacteria under greenhouse and two different field soil conditions. Soil Biol. Biochem. 38: 1482-1487. 
Table 1. Effect of chemical phosphorus alone or incombination with phosphate solubilizing bacteria on yield and nutrient uptale of wheat

\begin{tabular}{|c|c|c|c|c|c|c|c|c|c|c|c|c|}
\hline \multirow[t]{4}{*}{ Treatments } & \multicolumn{6}{|l|}{ Pabna } & \multicolumn{6}{|l|}{ Rajshahi } \\
\hline & \multirow{2}{*}{\multicolumn{2}{|c|}{ Yield $\left(\mathrm{t} \mathrm{ha}^{-1}\right)$}} & \multicolumn{4}{|c|}{ Nutrient uptake $\left(\mathrm{kg} \mathrm{ha}^{-1}\right)$} & \multirow{2}{*}{\multicolumn{2}{|c|}{ Yield $\left(\mathrm{t} \mathrm{ha}^{-1}\right)$}} & \multicolumn{4}{|c|}{ Nutrient uptake $\left(\mathrm{kg} \mathrm{ha}^{-1}\right)$} \\
\hline & & & \multicolumn{2}{|c|}{ Nitrogen } & \multicolumn{2}{|c|}{ Phosphorus } & & & \multicolumn{2}{|c|}{ Nitrogen } & \multicolumn{2}{|c|}{ Phosphorus } \\
\hline & Grain & Straw & Grain & Straw & Grain & Straw & Grain & Straw & Grain & Straw & Grain & Straw \\
\hline $\mathrm{T}_{0}$ & $1.53 \mathrm{c}$ & $3.59 \mathrm{c}$ & $26.94 b$ & $11.23 b$ & $3.94 \mathrm{c}$ & $0.47 \mathrm{~d}$ & $1.81 \mathrm{~d}$ & $4.14 \mathrm{~d}$ & $28.53 b$ & $13.34 b$ & $8.88 b$ & $0.55 \mathrm{c}$ \\
\hline $\mathrm{T}_{1}$ & $1.90 \mathrm{abc}$ & $4.59 \mathrm{bc}$ & $34.85 \mathrm{a}$ & $17.13 \mathrm{a}$ & $4.79 c$ & $0.78 b c$ & $2.15 \mathrm{c}$ & $5.98 \mathrm{c}$ & $32.81 \mathrm{ab}$ & $19.26 \mathrm{a}$ & $10.45 \mathrm{ab}$ & $1.01 \mathrm{~b}$ \\
\hline $\mathrm{T}_{2}$ & $1.63 b c$ & $4.48 \mathrm{bc}$ & $29.35 \mathrm{ab}$ & $17.06 \mathrm{a}$ & $4.48 \mathrm{c}$ & $0.62 \mathrm{~cd}$ & $2.24 \mathrm{c}$ & $6.03 \mathrm{bc}$ & $34.46 \mathrm{ab}$ & $19.95 \mathrm{a}$ & $10.93 \mathrm{ab}$ & $1.02 b$ \\
\hline $\mathrm{T}_{3}$ & $2.13 \mathrm{a}$ & $5.41 \mathrm{ab}$ & $36.72 \mathrm{a}$ & $18.23 \mathrm{a}$ & $7.25 \mathrm{a}$ & $1.34 \mathrm{a}$ & $2.79 \mathrm{ab}$ & $6.14 b$ & $42.65 \mathrm{a}$ & $20.17 \mathrm{a}$ & $13.40 \mathrm{a}$ & $1.27 \mathrm{ab}$ \\
\hline $\mathrm{T}_{4}$ & $2.11 \mathrm{a}$ & $4.91 \mathrm{ab}$ & $36.02 \mathrm{a}$ & $17.83 \mathrm{a}$ & $6.06 \mathrm{~b}$ & $0.91 b$ & $2.84 \mathrm{a}$ & $6.69 \mathrm{a}$ & $42.74 \mathrm{a}$ & $22.05 \mathrm{a}$ & $13.86 \mathrm{a}$ & $1.44 \mathrm{a}$ \\
\hline $\mathrm{T}_{5}$ & $2.00 \mathrm{ab}$ & $6.09 a$ & $34.65 \mathrm{a}$ & $18.16 \mathrm{a}$ & $5.95 \mathrm{~b}$ & $1.20 \mathrm{a}$ & $2.43 \mathrm{abc}$ & $6.09 \mathrm{bc}$ & $41.01 \mathrm{a}$ & $21.38 \mathrm{a}$ & $12.67 \mathrm{a}$ & $1.32 \mathrm{a}$ \\
\hline $\mathrm{CV}(\%)$ & 14.06 & 18.79 & 14.00 & 13.37 & 11.81 & 20.13 & 15.72 & 13.76 & 17.73 & 10.68 & 18.34 & 15.13 \\
\hline
\end{tabular}

Figures in a column having common letters do not differ significantly at 5 per cent level of significance, CV(\%)- co-efficient of variation

Table 2. Correlation coefficient among grain yield and yield contributing parameters of wheat at Pabna and Rajshahi

\begin{tabular}{|c|c|c|c|c|c|c|c|}
\hline Parameters & Grain yield & Plant height & Spike length & No. of tiller & Filled grain & Unfilled grain & 1000 seed weight \\
\hline \multicolumn{8}{|c|}{ Pabna } \\
\hline Grain yield & - & $0.849^{* *}$ & $0.867^{* *}$ & $0.929^{* *}$ & $0.935^{* *}$ & $-0.919^{* *}$ & $0.729^{* *}$ \\
\hline Plant height & & - & $0.688^{* *}$ & $0.774^{* *}$ & $0.943^{* *}$ & $-0.933^{* *}$ & $0.976^{* *}$ \\
\hline Spike length & & & - & $0.988^{* *}$ & $0.826^{* *}$ & $-0.703^{* *}$ & $0.583^{* *}$ \\
\hline No. of tiller & & & & - & $0.895^{* *}$ & $-0.789^{* *}$ & $0.666^{* *}$ \\
\hline Filled grain & & & & & - & $-0.936^{* *}$ & $0.885^{* *}$ \\
\hline Unfilled grain & & & & & & - & $-0.883^{* *}$ \\
\hline 1000 seed weight & & & & & & & - \\
\hline \multicolumn{8}{|c|}{ Rajshahi } \\
\hline Grain yield & - & $0.964^{* *}$ & $0.806^{* *}$ & $0.901^{* *}$ & $0.923^{* *}$ & $-0.208^{\mathrm{NS}}$ & $0.853^{* *}$ \\
\hline Plant height & & - & $0.927^{* *}$ & $0.923^{* *}$ & $0.954^{* *}$ & $-0.360^{*}$ & $0.888^{* * *}$ \\
\hline Spike length & & & - & $0.833^{* *}$ & $0.828^{* *}$ & $-0.522^{* *}$ & $0.816^{* *}$ \\
\hline No. of tiller & & & & - & $0.925^{* *}$ & $-0.542^{* *}$ & $0.952^{* *}$ \\
\hline Filled grain & & & & & - & $-0.350^{*}$ & $0.901^{* *}$ \\
\hline Unfilled grain & & & & & & - & $-0.398^{*}$ \\
\hline 1000 seed weight & & & & & & & - \\
\hline
\end{tabular}

